Review Article

\title{
Stories from the East: COVID-19 Situation in India
}

\author{
Rebecca Jane Joseph ${ }^{1}$, Hooi-Leng Ser ${ }^{1 *}$
}

Article History

Received: 8 April 2021;

Received in Revised Form:

3 June 2021;

\author{
${ }^{1}$ Novel Bacteria and Drug Discovery Research Group (NBDD), Microbes and \\ Bioresource Research Strength (MBRS), Jeffrey Cheah School of Medicine \\ and Health Sciences, Monash University Malaysia, 47500 Bandar Sunway, \\ Selangor, Malaysia; Rebecca.Jane@monash.edu (RJJ) \\ *Corresponding author: Hooi-Leng Ser, ser.hooileng@monash.edu (H-LS)
}

Accepted: 8 June 2021;

Available Online: 18 June 2021

\begin{abstract}
The war against COVID-19 is still ongoing since the first report in December 2019. On $1^{\text {st }}$ May 2021, India has reported over 400,000 new COVID-19 cases within 24 hours. The situation in the country continued to progress, which was associated with the reporting of the variant-of-concern and the variant-of-interest, including the B1.617 viruses. The government has taken public health measures, including campaigns to increase awareness about mask-wearing and physical distancing as well as lockdown plans to prevent further spread of the disease in the densely populated country. Furthermore, the countrywide vaccination program has begun in early 2021, while the government of India continues to monitor the COVID-19 situation in the country. The current review aims to provide a brief situation report in India before discussing management strategies taken and different phases of the vaccination program.
\end{abstract}

Keywords: SARS-CoV-2; COVID-19; situation; India; variants

\section{Introduction}

Since the ongoing COVID-19 pandemic, which was first reported in China around December 2019, there have been 172,630,637 confirmed cases and 3,718,683 deaths worldwide on the $7^{\text {th }}$ June $2021^{[1-7]}$. This has taken a significant toll both socially and economically throughout the world. Currently, India is a densely populated country severely affected by COVID-19 and experiencing one of the worst crises ${ }^{[8-10]}$. On $1^{\text {st }}$ May 2021, there were over 400,000 new COVID-19 cases for the first time within 24 hours in India. Based on data retrieved from the Ministry of Health and Family Welfare (MoHFW) on the $15^{\text {th }}$ May 2021, there was a total of 3,673,802 active cases, with 20,432,898 discharged and 266,207 deaths in total ${ }^{[11]}$. While many countries (including Australia, United Kingdom, Italy) have suspended traveling to and from India, the government of India has taken the approach to strictly enforce the Test-Track-Treat protocol throughout the country, emphasizing the public to adhere to COVID-appropriate behavior and to boost the vaccination drive ${ }^{[12,13]}$. Several steps are taken using the Test-Track-Treat protocol, such as increasing the number of testing using real time-PCR (RT-PCR) to more than $70 \%$, quarantine new positive cases as 
soon as possible, and tracing their contacts sooner. The containment zones are demarcated meticulously updated on the network page by each District Collectors and by the States, and this information is regularly shared with the MoHFW ${ }^{[14]}$. These measurements ensure close monitoring for any influenza-like illness (ILI) or severe acute respiratory infections (SARI) cases, house-to-house surveillance, and strict perimeter control. In addition, COVID appropriate behavior such as wearing a face mask, physical distancing, and hand hygiene have been strictly enforced; failure to comply with the law will result in imposition of fines and administrative actions.

\section{Important Events Since the First COVID-19 Case Reported in 2020}

The first confirmed case on the $30^{\text {th }}$ January 2020 was a patient who returned from Wuhan to Kerala ${ }^{[15,16]}$. Until $3^{\text {rd }}$ February 2020, only three confirmed cases were reported in Kerala who were all stable and isolated in the hospital. The government of India ensured those who have returned from China since $15^{\text {th }}$ January 2020 undergo a mandatory quarantine for 14 days and issued travel advisories requesting the public to refrain from traveling to the specified country. At the same time, the Ministry of Tourism has also taken initiatives to coordinate with the Hotels Association in India to encourage the public to report themselves if they have visited any tourists of religious areas. The World Health Organization (WHO) declared the COVID-19 outbreak as a pandemic on $11^{\text {th }}$ March 2020, and the Government of India announced this as a notified disaster under the Disaster Management Act 2005 ${ }^{[17]}$. Travelers from China, Iran, Italy, France, Germany, Spain and the Republic of Korea after $15^{\text {th }}$ February 2020 were mandated to quarantine for at least 14 days. There were 84 cases of Covid-19 reported in India, and two deaths were reported on the $14^{\text {th }}$ March 2020. Cases were from 13 states in India, mainly originating in Kerala (19 cases) followed by Maharashtra (14 cases), Haryana (14 cases), Uttar Pradesh (12 cases), Delhi (7 cases), Karnataka (6 cases), Ladakh (3 cases), Rajasthan (3 cases), Jammu \& Kashmir (2 cases), Andhra Pradesh (1 case), Punjab (1 case), Telangana (1 case) and Tamil Nadu (1 case). A 76 years old male from Karnataka and 68 years old female from Delhi with underlying comorbidities passed away. Due to the rise in cases, "Janata curfew" for 14 hours from 7.00 a.m. to 9.00 p.m. was announced by the Prime Minister of India, Narendra Modi on $22^{\text {nd }}$ March 2020, pleading to the public to stay at home and to observe social distancing ${ }^{[18]}$. MoHFW had also taken precautionary steps to ensure sufficient isolation wards, personal protective equipment (PPEs), medicines, testing kits and workers. As thousands of cases continue to spike per day, the Prime Minister of India issued a lockdown throughout the country starting on the $25^{\text {th }}$ March 2020. However, the lockdown was further extended thrice till $31^{\text {st }}$ May 2020 $0^{[19-21]}$. International flights were suspended from $25^{\text {th }}$ March till $14^{\text {th }}$ April 2020, and any interstate travel was restricted ${ }^{[22]}$. During the lockdown period, the government of India has taken the opportunity to make advancements in the healthcare system and infrastructures. There were 930 dedicated COVID hospitals with 158,747 isolation beds, 20,355 ICU beds, 69,076 oxygen supported beds, and 2,362 dedicated COVID Health Centres with 132,593 isolation beds; 10,903 ICU beds and 45,562 oxygen supported beds operationalized as reported by MoFHW on $27^{\text {th }}$ May $2020^{[23,24]}$. 
Furthermore, during the Global Vaccine Summit 2020, the Prime Minister of India emphasized the ability of India to produce quality vaccines and medicines with minimal costs, and 15 million USD was pledged to the Vaccine Alliance, GAVI ${ }^{[25]}$. The Indian Council of Medical Research and State authorities also ensured that no individual was restricted from being tested. Although RT-PCR is the gold standard to diagnose COVID-19, the government of India has decided to increase more Rapid Antigen tests because it is safe, simple, and provides quicker results. There were also 788 in the government sector and 317 private labs, making it up to a total of $1,105 \mathrm{labs}^{[26]}$. Along with this, the Government of India launched the "Aarogya Setu" mobile application that uses Bluetooth technology to aid in surveillance and contact tracing ${ }^{[27]}$. The application is available in 11 languages and can be installed into smartphones, allowing users to determine the risk of catching infection based on their interaction with others ${ }^{[28]}$. Besides that, a video consultation program called e-ICU was started by New Delhi-based All India Institute of Medical Sciences (AIIMS) across the country on the $8^{\text {th }}$ July to allow front liners to share their experiences in treating COVID-19 patients and have discussions with other experts in this field using this platform ${ }^{[29]}$.

Ministry of Home Affairs issued guidelines on the $30^{\text {th }}$ September on re-opening some states, but the lockdown continued in containment zones until the $30^{\text {th }}$ November $2020^{[30]}$. On the $8^{\text {th }}$ October 2020, 'Jan Andolan' was launched to closely observe these three appropriate behaviors: social distancing of six feet, wearing a mask and washing hands often $^{[31]}$. In November 2020, daily new cases of COVID-19 and the number of deaths per million started to decline and was much lesser compared to some parts of the world. Ever since mid-September 2020, the lowest case number of 9,110 was reported on $9^{\text {th }}$ February 2021. However, a surge of cases returned in some states with 14,264 cases on the $21^{\text {st }}$ February 2021 and continues to spike within two weeks with an almost $43 \%$ increase of COVID-19 cases and $37 \%$ new deaths on a weekly basis. The national capital of India, New Delhi was heavily affected during the second wave and has been under lockdown since the $19^{\text {th }}$ April 2021 $1^{[32]}$. Based on the situation report of $28^{\text {th }}$ April 2021, India has the highest daily cases ${ }^{[33]}$. At that point in time, India was ranked fourth highest in terms of the number of deaths with a case fatality ratio of $1.12 \%$ in the world. The leading state with more than four million cases is Maharashtra followed by a million over cases in Kerala, Karnataka, Uttar Pradesh, and Tamil Nadu ${ }^{[34]}$. On $1^{\text {st }}$ May 2021, India has become the first country to record over 400,000 new COVID-19 cases within 24 hours since the pandemic. There were 401,993 new infections with a total of 19.1 million cases and 3,523 deaths, adding up the total number of deaths to $211,853^{[35,36]}$. Two weeks later, these figures continue to rise, resulting in a total of 3,673,802 active cases, with 20,432,898 discharged and 266,207 deaths ${ }^{[11]}$. As of $1^{\text {st }}$ June 2021, the data retrieved from WHO Coronavirus (COVID-19) Dashboard (https://covid19.who.int/) recorded a total of 28,208,619 confirmed cases and 331,899 total deaths in India. 


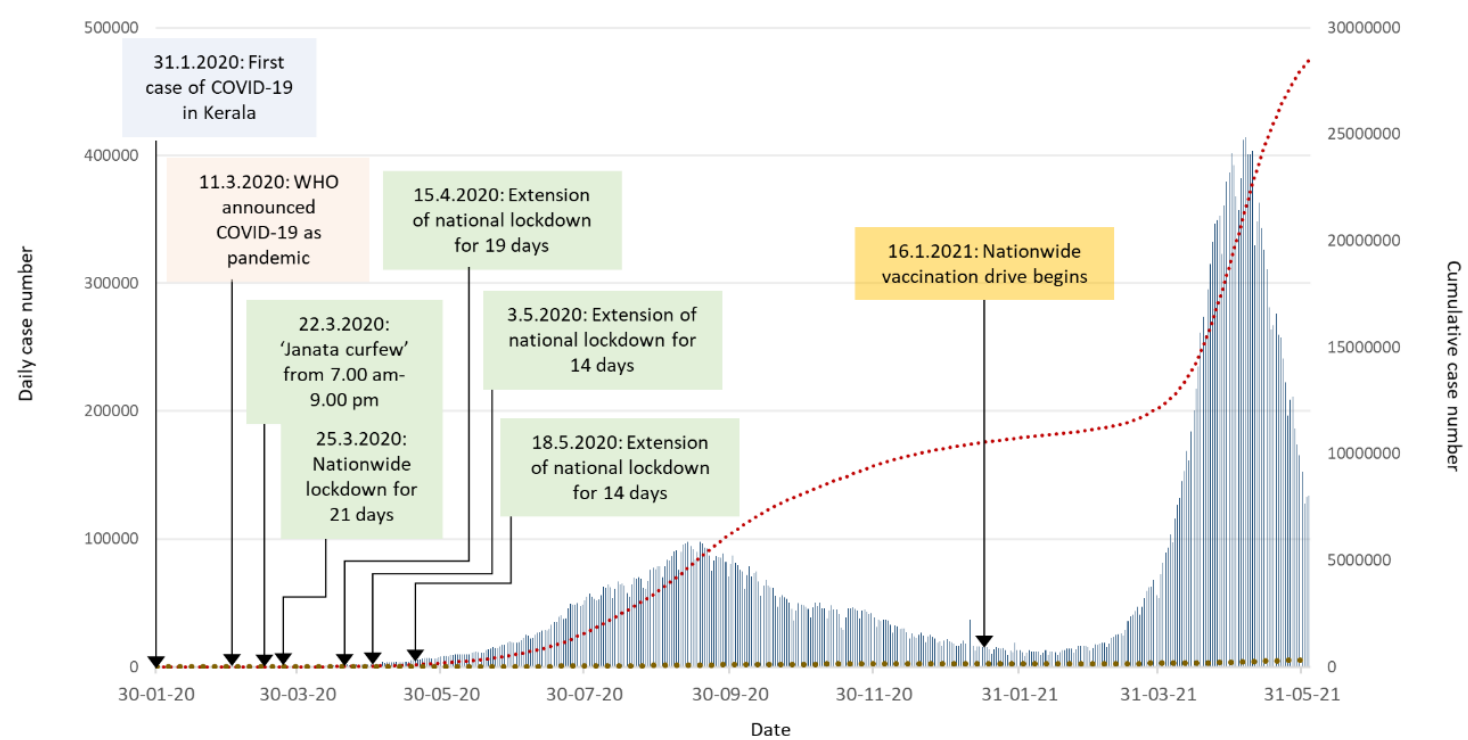

Figure 1. Illustration of daily confirmed COVID-19 cases, cumulative COVID-19 cases, cumulative deaths due to COVID-19, and a brief timeline of the events in India since the first case reported in the country.

\section{Combating COVID-19: Medications and Vaccination Program in India}

Along with Directorate General of Health Services, MoHFW, and Indian Council of Medical Research's ICMR-COVID-19 National task force, AIIMS has recently published an updated comprehensive guideline for the management of COVID-19 adult patients, removing recommendations on hydroxychloroquine and convalescent plasma use ${ }^{\text {[37-39]. }}$. Based on the guidelines, the use of medications like remdesivir (under Emergency Use Authorisation) and tocillizumab (off-label use) should be considered carefully and not to be used in mild COVID-19 patients. Additionally, the exportation of remdesivir injection has been prohibited since the $11^{\text {th }}$ April 2021. Remdesivir manufacturers also had to ramp up their production to $7,400,000$ of vials every month. Twenty more manufacturing sites have been approved to meet the demands of hospitalized patients on oxygen support in 19 states ${ }^{[40]}$. As for the case of steroids, the guideline emphasized that they should be used at "right time, right dose and for the right duration", only in hospitalized moderately severe and critically ill COVID-19 patients.

On the $9^{\text {th }}$ January 2021, the Prime Minister of India has shared on his social media account and issued a press release that $16^{\text {th }}$ January represents a "landmark step" for the country in the fight of COVID-19, as the national-wide vaccination drive begins, intending to vaccinate 300 million people by July $2021^{[41]}$. Phase I of the National Covid-19 Vaccination Strategy targeted healthcare and frontline workers with more than $60 \%$ vaccinated within a month $^{[42]}$. The registrations and booking for vaccination appointment for phase 2 using the COWIN portal or via the "Aarogya Setu" mobile application started on $1^{\text {st }}$ March 2021, for those 60 years old and above as well as those aged between 45-59 with comorbidities that accounted for more than $80 \%$ of mortality in the country. Subsequently, the government announced the "Liberalised and Accelerated Phase 3 Strategy of Covid-19 Vaccination" to include individuals above 18 years old with registration opening from $28^{\text {th }}$ April 2021 and 
vaccination begun from the $1^{\text {st }}$ May $2021^{[43]}$. Vaccination is provided free of charge at the Government Vaccination Centres ${ }^{[43-49]}$. At the time of writing, the National Regulator (Drugs Controller General of India) has granted Emergency Use Authorisation (EUA) of the COVISHIELD ${ }^{\circledR}$ (AstraZeneca's vaccine), manufactured by Serum Institute of India (SII) with an efficacy of $62-90 \%$, and COVAXIN manufactured by ICMR in collaboration with Bharat Biotech International Limited (BBIL). COVAXIN phase 1 and 2 clinical trials conducted around July till October 2020 on 755 participants showed promising results and safety profiles. The largest clinical trial conducted on 25,800 participants also showed $81 \%$ efficacy against the SARS-CoV-2 virus in early March. The Drugs Controller of India (DCGI) has already approved COVAXIN for the Restricted Use in Emergency Situation. Russia's Sputnik V, the third vaccine, was approved in India in mid-April. Within merely 26 days, India becomes the fastest country to reach a milestone of vaccinating 7,000,000 citizens $^{[50]}$. On top of that, the Union Minister for Health and Family Welfare, Dr. Harsh Vardhan has also reassured the safety of both the vaccines and efficacy against current strains, stating that the percentage of severe Adverse Events Following Immunisation is $0.0002 \%$ of the total number of beneficiaries vaccinated ${ }^{[51]}$. As of $1^{\text {st }}$ May $2021,156,816,031$ vaccines have been administered, and $28,644,878$ have already received their second dose $\mathrm{e}^{[52]}$.

\section{Emergence of Variant-of-concern (VOC) and Variant-of-interest (VOI): B.1.617 Viruses}

The genomic changes SARS-CoV-2 through whole-genome sequencing (WGS) is continuously being monitored by the Indian SARS-CoV-2 Genomics Consortium (INSACOG) since December 2020. Out of 13,614 WGS samples processed in a network of 10 laboratories, 1,189 samples tested positive for variants of concern which are 1,109 UK variants; 79 variants which were firstly described in South Africa, and 1 of them was the variant firstly described in Brazil as of $15^{\text {th }}$ April $2021^{[53]}$. For the past few weeks, the steep rise of cases across India has spread to about 40 nations, including Singapore, United Kingdom, and Fiji was associated with the B.1.617 variant ${ }^{[54,55]}$. The B.1.617 viruses are categories into three lineages: B.1.617.1, B.1.617.2 and B.1.617.3 ${ }^{[56]}$. On the $1^{\text {st }}$ June 2021, the WHO released a public statement to facilitate communication regarding the naming of VOC and VOI to avoid country (or area) stigma ${ }^{[57]}$. In the same report, they have revised the status of VOC and VOI, labeling B.1.617.2 or variant Delta as VOC and B.1.617.1 as variant Kappa as VOI. B.1.617.3 is no longer listed as VOC or VOI due to few reports of the variants as pointed out by the WHO. While some studies are investigating the spread of different SARS-CoV-2 variants around the world, there are ongoing discussion revolving the efficacy of vaccines ${ }^{[58-64]}$. Several teams believed that the double mutation results in a more virulent variant. Till then, more studies are necessary to fully understand how these genomic changes contribute to the virulence and "behaviour" of these variants, particularly whether these changes would affect the efficacy of vaccines ${ }^{[65-68]}$.

\section{Conclusions}

The constant updates on COVID-19 situations from official authorities have allowed citizens to access the latest information quickly. The statistics on vaccination in India 
continue to rise, enabling the community to achieve immunity against COVID-19 in due time. The next hurdle for universal control of the pandemic would involve successful immunization programs globally ${ }^{[69]}$. Some countries are struck with vaccine shortages as well as economic and logistic issues ${ }^{[32,69-72]}$. For India, several organizations and governments have started delivering critical lifesaving supplies and medicines to support the country's healthcare system ${ }^{[73-75]}$. The war against COVID-19 is not over yet and has taught the world not to take this pandemic lightly. Previous collaborative efforts between countries have yielded success in developing vaccines following the availability of genome sequences of SARS-CoV-2 viruses. Moving forward, everyone needs to join hands to break the transmission chain and curb the spread of this notorious coronavirus.

Author Contributions: R.J.J performed the literature search, critical data analysis as well as manuscript writing. H.-L.S. proofread the review writing and conceptualise this review writing project.

Funding: The SEED Funding funded this work from Microbiome and Bioresource Research Strength (MBRS), Jeffrey Cheah School of Medicine and Health Sciences, (Vote Number: MBRS/JCSMHS/02/2020) and Jeffrey Cheah School of Medicine and Health Sciences (JCSMHS) Strategic Grant 2021 (Grant Code: STG-000051).

Conflicts of Interest: The authors declare no conflict of interest.

\section{References}

1. World Health Organisation. WHO Coronavirus (COVID-19) Dashboard. 2021 [Accessed 15 May 2021; Available from: https://covid19.who.int/.

2. Ser H-L, Letchumanan V, Law JW-F, et al., PMMB COVID-19 Bulletin: Spain (18 $8^{\text {th }}$ April 2020). Prog Microbes Mol Biol 2020; 3(1).

3. Tan LT-H, Letchumanan V, Ser H-L, et al., PMMB COVID-19 Bulletin: United Kingdom (22 ${ }^{\text {nd }}$ April 2020). Prog Microbes Mol Biol 2020; 3(1).

4. Hong Chuan Loh YKS, Irene Looi, The COVID-19 Pandemic and Diet Change. Prog Microbes Mol Biol 2021; 4: a0000203.

5. Goh HP, Mahari WI, Ahad NI, et al., Risk factors affecting COVID-19 case fatality rate: A quantitative analysis of top 50 affected countries. medRxiv 2020.

6. Letchumanan V, Ab Mutalib N-S, Goh B-H, et al., Novel coronavirus 2019-nCoV: Could this virus become a possible global pandemic. Prog Microbes Mol Biol 2020; 3(1).

7. $\mathrm{Ng} \mathrm{SL}$, Ong YS, Khaw KY, et al., Focused review: potential rare and atypical symptoms as indicator for targeted COVID-19 screening. Med 2021; 57(2): 189.

8. Johnson D, Ren SEC, Johnson HD, et al., COVID-19: Are Malaysians embracing or suffering the new normality? Prog Microbes Mol Biol 2020; 3(1).

9. Dev SM and Sengupta R, Covid-19: Impact on the Indian economy. Indira Gandhi Institute of Development Research, Mumbai April 2020.

10. Wang C, Tee M, Roy AE, et al., The impact of COVID-19 pandemic on physical and mental health of Asians: A study of seven middle-income countries in Asia. PloS one 2021; 16(2): e0246824.

11. Ministry of Health and Family Welfare-Government of India. COVID-19 status. 2021 [Accessed 15 May 2021; Available from: https://www.mohfw.gov.in/

12. travel C. Travel to India during Covid-19: What you need to know before you go. 2021 [Accessed 15 May 2021; Available from: https:/edition.cnn.com/travel/article/india-travel-covid-19/index.html. 
13. World Health Organisation-India. Situation Update Report-65. 2021 [Accessed 14 May 2021; Available from: https://cdn.who.int/media/docs/default-source/wrindia/situation-report/india-situation-report-65.pdf?sfvrsn=712 919f8 4.

14. Press Information Bureau, Government of India. MHA Guidelines for effective control of COVID-19. 2021 [Accessed 12 May 2021; Available from: https://www.pib.gov.in/PressReleasePage.aspx?PRID=1706966.

15. World Health Organisation-India. Situation Update Report-4. 2020 [Accessed 14 May 2021; Available from: https://cdn.who.int/media/docs/default-source/wrindia/situation-report/india-situation-report-4fc11fed6bd46408 3b4ce93b26097391e.pdf?sfvrsn=d257be4b 2.

16. Sharma S, Basu S, Shetti NP, et al., Current treatment protocol for COVID-19 in India. Sensors International 2020; 1: 100013.

17. World Health Organisation-India. Situation Update Report-7. 2020 [Accessed 12 May 2021; Available from: https://cdn.who.int/media/docs/default-source/wrindia/situation-report/india-situation-report-7.pdf?sfvrsn=cf4a7 $\underline{3122}$.

18. World Health Organisation-India. Situation Update Report-8. 2020 [Accessed 13 May 2021; Available from: https://cdn.who.int/media/docs/default-source/wrindia/situation-report/india-situation-report-8bc9aca340f91408 b9efbedb3917565fc.pdf? sfvrsn=5e0b8a43_2.

19. World Health Organisation-India. Situation Update Report-12. 2020 [Accessed 13 May 2021; Available from: https://cdn.who.int/media/docs/default-source/wrindia/situation-report/india-situation-report-12.pdf?.sfvrsn=222 $\underline{83 \mathrm{a} 8 \mathrm{a} \_2 \text {, }}$

20. World Health Organisation-India. Situation Update Report-14. 2020 [Accessed 13 May 2021; Available from: https://cdn.who.int/media/docs/default-source/wrindia/situation-report/india-situation-report-14.pdf?sfvrsn=9a7 42871_2.

21. Press Information Bureau GoI. Extension of Lockdown up to May 31, 2020. 2020 [Accessed 1 June 2021]; Available from: https://pib.gov.in/PressReleasePage.aspx?PRID=1624763.

22. World Health Organisation-India. Situation Update Report-9. 2020 [Accessed 14 May 2021; Available from: https://cdn.who.int/media/docs/default-source/wrindia/situation-report/india-situation-report-9.pdf?sfvrsn=c883 d0c2 2 .

23. World Health Organisation-India. Situation Update Report-18. 2020 [Accessed 13 May 2021; Available from: https://cdn.who.int/media/docs/default-source/wrindia/situation-report/india-situation-report-18.pdf?sfvrsn=7c0 $\underline{0 a 3 f 2 .}$.

24. Press Information Bureau GoI. Updates on COVID-19. 2020 [Accessed 2 June 2021; Available from: https://pib.gov.in/PressReleasePage.aspx?PRID=1627179.

25. World Health Organisation-India. Situation Update Report-19. 2020 [Accessed 13 May 2021; Available from: https://cdn.who.int/media/docs/default-source/wrindia/situation-report/india-situation-report-19.pdf?sfvrsn=14c 7933f 2.

26. Press Information Bureau, Government of India. COVID Tests cross 1 crore milestone. 2020 [Accessed 13 May 2021; Available from: https://pib.gov.in/PressReleasePage.aspx?PRID=1636823.

27. Press Information Bureau, Government of India. Dr. Harsh Vardhan addresses the 4th edition of Future Investment Initiative Forum. 2021 [Accessed 14 May 2021; Available from: https://www.pib.gov.in/PressReleasePage.aspx?PRID=1692800. 
28. Press Information Bureau, Government of India. Government of India launches ArogyaSetu App to track Covid 19 infection. 2020 [Accessed 14 May 2021; Available from: https://pib.gov.in/PressReleaseIframePage.aspx?PRID=1610326.

29. Press Information Bureau, Government of India. AIIMS New Delhi’s “e-ICU” Video Consultation Program Gains Traction 43 Big Hospitals in 11 States Covered So far. 2020 [Accessed 14 May 2021; Available from: https://pib.gov.in/PressReleasePage.aspx?PRID=1639872.

30. Press Information Bureau GoI. MHA issues new Guidelines for Re-opening. 2020 [Accessed 2 June 2021; Available from: $\underline{\text { https://pib.gov.in/PressReleasePage.aspx?PRID=1660432. }}$

31. Press Information Bureau, Government of India. MHA extends the Guidelines for Re-opening. 2020 [Accessed 14 May 2021; Available from: https://www.pib.gov.in/PressReleasePage.aspx?PRID=1667821.

32. CNN World News. India is spiraling deeper into Covid-19 crisis. Here's what you need to know. 2021 [Accessed 15 May 2021; Available from:

https:/edition.cnn.com/2021/04/26/india/india-covid-second-wave-explainer-intl-hnk-dst/index.html.

33. Khare V, India's Kumbh festival attracts big crowds amid devastating second Covid wave, in BBC Hindi, Delhi. 2021.

34. Press Information Bureau, Government of India. 70 districts in 16 states have shown around 150\% rise in COVID-19 cases over the last 15 days: Union Health Secretary. 2021 [Accessed 14 May 2021; Available from: https://www.pib.gov.in/PressReleasePage.aspx?PRID=1705577.

35. Updates CLNL. Coronavirus Latest News LIVE Updates: India Records Over 4 Lakh Covid Cases In 24 Hours In New High. 2021 [Accessed 14 May 2021; Available from:

https://www.ndtv.com/india-news/india-coronavirus-latest-news-live-updates-over-3-86-lakh-covid-19-cases-inindia-in-last-24-hours-1-may-2021-2425676.

36. Star T. India records over 400,000 Covid-19 cases in 24 hours; Ahmedabad hospital fire kills 16 Covid patients, two nurses. 2021 [Accessed 12 May 2021; Available from:

https://www.thestar.com.my/aseanplus/aseanplus-news/2021/05/01/india-records-over-400000-covid-19-cases-i n-24-hours-ahmedabad-hospital-fire-kills-16-covid-patients-two-nurses.

37. Government of India. Clinical Management Protocol: COVID-19 Version 4. 2020 [Accessed 2 June 2021; Available from: https://www.mohfw.gov.in/pdf/ClinicalManagementProtocolforCOVID19dated27062020.pdf.

38. Press Information Bureau, Government of India. Union Health Ministry issues updated clinical management protocol for managing COVID-19 cases. 2020 [Accessed 13 May 2021; Available from: https://www.pib.gov.in/PressReleasePage.aspx?PRID=1634725.

39. Directorate General of Health Services, MoHFW, GOI. Comprehensive Guidelines for Management of COVID-19 patients. 2021 [Accessed 2 June 2021; Available from:

https://ghs.gov.in/WriteReadData/News/202105270436027770348ComprehensiveGuidelinesforManagementof COVID-1927May2021DteGHS.pdf.

40. Press Information Bureau, Government of India. Union Government allocates supply of Remdesivir to 19 States/UTs with High Burden of COVID cases. 2021 [Accessed 12 May 2021; Available from: https://www.pib.gov.in/PressReleasePage.aspx?PRID=1713329.

41. News B. Covid: India to begin vaccine rollout on 16 January. 2021 [Accessed 14 May 2021; Available from: https://www.bbc.com/news/world-asia-india-55603620.

42. Prime Minister Office of India. News update: India is expressing its gratitude to frontline Corona warriors by giving them priority in vaccination: PM. 2020 [Accessed 2 June 2021; Available from: 
https://www.pmindia.gov.in/en/news updates/cabinet-approves-signing-and-ratification-of-an-agreement-on-co operation-in-the-field-of-mass-media-between-all-the-member-states-of-shanghai-cooperation-organisation/?co $\underline{\text { mment }=\text { disable. }}$.

43. Press Information Bureau, Government of India. Government of India announces a Liberalised and Accelerated Phase 3 Strategy of Covid-19 Vaccination from 1st May. 2021 [Accessed 14 May 2021; Available from: https://www.pib.gov.in/PressReleasePage.aspx?PRID=1712710.

44. Press Information Bureau, Government of India. Phase 3 Clinical Trial of COVAXIN, developed by ICMR \& Bharat Biotech, shows 81\% efficacy. 2021 [Accessed 14 May 2021; Available from: https://www.pib.gov.in/PressReleasePage.aspx?PRID=1702293.

45. Press Information Bureau, Government of India. After 1st May, every person above 18 years can be vaccinated. Half of the vaccine produced in India will go directly to the states and hospitals: PM. 2021 [Accessed 14 May 2021; Available from: https://www.pib.gov.in/PressReleasePage.aspx?PRID=1713113.

46. Press Information Bureau, Government of India. Russia's Sputnik V has been approved for emergency use in India, Govt. authorises foreign-produced COVID vaccines with emergency approval of WHO-listed agencies. 2021 [Accessed 14 May 2021; Available from: https://www.pib.gov.in/PressReleasePage.aspx?PRID=1711558.

47. Ministry of Health and Family Welfare-Government of India. COVID-19 Vaccine FAQs. 2021 [Accessed 14 May 2021; Available from: https:/www.mohfw.gov.in/covid_vaccination/vaccination/faqs.html\#vaccine-registration.

48. BBC News. Sputnik V, Covishield, Covaxin: What we know about India's Covid-19 vaccines. 2021 [Accessed 15 May 2021; Available from: https://www.bbc.com/news/world-asia-india-55748124.

49. PIB Delhi. Phase 3 Clinical Trial of COVAXIN, developed by ICMR \& Bharat Biotech, shows 81\% efficacy. 2021 [Accessed 12 May 2021; Available from: https://pib.gov.in/PressReleasePage.aspx?PRID=1702293.

50. World Health Organisation-India. Situation Update Report-55. 2021 [Accessed 13 May 2021]; Available from: https://cdn.who.int/media/docs/default-source/wrindia/situation-report/india-situation-report-55.pdf?sfvrsn=4e5 7a904_4.

51. Press Information Bureau, Government of India. Government is ensuring supplies of vaccines to the states as per their per day vaccination capacities. 2021 [Accessed 14 May 2021]; Available from: https://www.pib.gov.in/PressReleasePage.aspx?PRID=1707861.

52. Ministry of Health and Family Welfare-Government of India. Cumulative Coverage Report of COVID-19 Vaccination. 2021 [Accessed 13 May 2021; Available from: https://www.mohfw.gov.in/pdf/CumulativeCOVIDVaccinationCoverageReport1stMay2021.pdf.

53. Press Information Bureau, Government of India. Indian Genomic Consortium has so far processed more than 13,000 samples for Genome Sequencing. 2021 [Accessed 15 May 2021; Available from: https://www.pib.gov.in/PressReleasePage.aspx?PRID=1712312.

54. Dyer O, Covid-19: India sees record deaths as "black fungus” spreads fear. 2021, British Medical Journal Publishing Group.

55. Loo K-Y, Letchumanan V, COVID-19: Malaysia's fight against this deadly virus Prog Microbes Mol Biol 2021; 4: a0000204.

56. Organisation WH. COVID-19 Weekly Epidemiological Update. 2011 [Accessed 3 June 2021]; Available from: https:/www.who.int/publications/m/item/weekly-epidemiological-update-on-covid-19---11-may-2021.

57. Organisation WH. COVID-19 Weekly Epidemiological Update, Edition 42. 2021 [Accessed 3 June 2021]; Available from: https:/www.who.int/publications/m/item/weekly-epidemiological-update-on-covid-19---1-june-2021. 
58. News NPR. People Are Talking About A 'Double Mutant' Variant In India. What Does That Mean? 2021 [Accessed 15 May 2021; Available from: https:/www.npr.org/sections/goatsandsoda/2021/04/24/988744811/people-are-talking-about-a-double-mutant-v ariant-in-india-what-does-that-mean.

59. Control ECfDPa. Threat Assessment Brief: Emergence of SARS-CoV-2 B.1.617 variants in India and situation in the EU/EEA. 2021 [Accessed 15 May 2021; Available from:

https://www.ecdc.europa.eu/sites/default/files/documents/Emergence-of-SARS-CoV-2-B.1.617-variants-in-Indi a-and-situation-in-the-EUEEA 0.pdf.

60. Bernal JL, Andrews N, Gower C, et al., Effectiveness of COVID-19 vaccines against the B. 1.617. 2 variant. medRxiv 2021.

61. Wise J, Covid-19: Second vaccine doses expedited in areas of England where new variant is high. 2021, British Medical Journal Publishing Group.

62. Quinonez E, Vahed M, Hashemi Shahraki A, et al., Structural Analysis of the Novel Variants of SARS-CoV-2 and Forecasting in North America. Viruses 2021; 13(5): 930.

63. Vohringer HS, Sanderson T, Sinnott M, et al., Genomic reconstruction of the SARS-CoV-2 epidemic across England from September 2020 to May 2021. medRxiv 2021.

64. Vaidyanathan G, Coronavirus variants are spreading in India — what scientists know so far. Nature 2021; 593(7859): 321-322.

65. Zhong M, Lin B, Pathak JL, et al., ACE2 and furin expressions in oral epithelial cells possibly facilitate COVID-19 infection via respiratory and fecal-oral routes. Front Med 2020; 7.

66. Ser H-L, Tan LT-H, Law JW-F, et al., Genomic analysis of severe acute respiratory syndrome coronavirus 2 (SARS-CoV-2) strains isolated in Malaysia. Prog Microbes Mol Biol 2020; 3(1).

67. Uddin M, Mustafa F, Rizvi TA, et al., SARS-CoV-2/COVID-19: viral genomics, epidemiology, vaccines, and therapeutic interventions. Viruses 2020; 12(5): 526

68. Lee VS, Chong WL, Sukumaran SD, et al., Computational screening and identifying binding interaction of anti-viral and anti-malarial drugs: Toward the potential cure for SARS-CoV-2. Prog Microbes Mol Biol 2020; 3(1).

69. Priyanka P, Choudhary OP, and Singh I, Making sound public health decisions for the roll-out of COVID-19 vaccines. J Travel Med 2021.

70. Sisa I, Noblecilla E, and Orozco F, Rationale to continue approving placebo-controlled COVID-19 vaccine trials in LMICs. The Lancet 2021; 397(10277): 878.

71. Barnabas RV and Wald A, A public health COVID-19 vaccination strategy to maximize the health gains for every single vaccine dose. 2021, American College of Physicians.

72. Loo K-Y, Letchumanan V, Ser H-L, et al., COVID-19: Insights into potential vaccines. Microorganisms 2021; 9(3): 605 .

73. Hunter J, India Covid aid: Is emergency relief reaching those in need?, in BBC News. 2021.

74. Times NS. UNICEF Malaysia launches fund to help India fight Covid-19. 2021 [Accessed 1 June 2021; Available from:

https://www.nst.com.my/news/nation/2021/05/688031/unicef-malaysia-launches-fund-help-india-fight-covid-19 
75. The Star News. India's daily COVID-19 cases pass 400,000 as second wave worsens. 2021 [Accessed 15 May 2021; Available from:

https://www.thestar.com.my/news/world/2021/05/01/india-posts-record-daily-rise-in-covid-19-cases-of-401993

Author(s) shall retain the copyright of their work and grant the Journal/Publisher right for the first publication with the work simultaneously licensed under:

Creative Commons Attribution-NonCommercial 4.0 International (CC BY-NC 4.0). This license allows for the copying, distribution and transmission of the work, provided the correct attribution of the original creator is stated. Adaptation and remixing are also permitted. 